\title{
The Effect of Empowerment, Training, Compensation through Organizational Commitment on the Performance of the Financial Management of the North Sulawesi Provincial Government
}

\author{
Zainudin Hilimi \\ Universitas Negeri Jakarta \\ Email: zainudinhilimi_im10s3@mahasiswa.unj.ac.id \\ Paulus Kindangen \\ Universitas Sam Ratulangi \\ Email: Pkindangen@unsrat.ac.id \\ Dewi Susita \\ Universitas Negeri Jakarta \\ Email: dewisusita_man@unj.ac.id
}

\begin{abstract}
This study aims to analyze and determine the effect of empowerment, training, compensation through organizational commitment to the financial management performance of the North Sulawesi Provincial Government. The methodology used in this research is a quantitative approach with a descriptive survey method. Research respondents numbered 267 financial management employees.

The results of this study indicate that 1) Empowerment has a direct and positive effect on the performance of financial management employees. 2) Training has a direct and positive effect on the performance of financial management employees. 3) Compensation has a direct and positive effect on the performance of financial management employees. 4) Organizational commitment has a direct and positive effect on the performance of financial management employees. 5) Empowerment of employees has a direct and positive effect on organizational commitment of financial management employees. 6) Employee training has a direct and positive effect on organizational commitment of financial management employees. 7) Compensation has a direct and positive effect on organizational commitment of financial management employees. 8) Empowerment of employees has an indirect and positive effect on employee performance through organizational commitment. 9) Employee Training has an indirect and positive effect on employee performance through organizational commitment. 10) Employee compensation has an indirect and positive effect on employee performance through organizational commitment.

Based on the results of this study it can be concluded that there is an influence of empowerment, training and compensation through organizational commitment to the financial management performance of the North Sulawesi Provincial Government, for this reason the results of this study can be used as reference material for the Leaders of Regional Apparatuses in the North Sulawesi Provincial Government in making policies concerning performance improvement in the area of financial management.
\end{abstract}

Keywords: Empowerment, Training, Compensation, Organizational Commitment, Performance 
Received: 7 February 2020 ;

Accepted: 8 April 2020 ;

Publish; December 2020.

\section{How to Cite:}

Hilimi, Z., Kindangen, P., \& Susita, D. (2020). The Effect of Empowerment, Training, Compensation through Organizational Commitment on the Performance of the Financial Management of the North Sulawesi Provincial Government. International Journal of Human Capital Management, 4 (2), 1-10. https://doi.org/10.21009/IJHCM.04.02.01

\section{INTRODUCTION}

The North Sulawesi Provincial Government is always on time in determining the regional income and expenditure budget (APBD) every year, where the APBD is always set 1 (one) month before the fiscal year is implemented. However, the implementation of the APBD always faces constraints, resulting in the end of each year there is always a More Over Budget Calculation (SiLPA) that is quite material. The implementation of programs and activities contained in the APBD is also influenced by the performance of regional financial management. The number of programs and activities carried out, as well as the many procedures and regulations that must be obeyed in financial management, require financial managers to be able to provide services with adequate performance.

Preliminary observations made on the employees of the regional financial management in the North Sulawesi Province government, especially regarding performance, were found that the performance of the employees could not be said to be maximal because it was indicated: 1) employees were still unable to work quickly in completing work, especially in the field of financial management, 2) financial management employees tend to wait for superiors' orders in completing work, 3) the lack of ability of some employees in mastering and understanding and carrying out financial management tasks 4) the quality of work produced by employees is not all optimal as expected, 5) not yet all employees are able to utilize working hours effectively, 6) Training that is attended by financial management employees is not all really related to the duties and functions as financial managers so that even though employees attend the training not all material is really obtained can be applied when carrying out tasks, 7) Provision of additional income tends not to affect the work of employees, 8) Financial management employees are less responsible for their main tasks such as undisciplined entry and return from work, and undisciplined in completing work that is their job whereas the characteristics- Characteristics of employees who have organizational commitment are having loyalty and responsibility, carrying out the vision, mission and goals of the organization. 9) Lack of employee's "sense of belonging" to the organization. These conditions, tend to result in less effective services or even less reflect the service joints as regulated in Kepmenpan No. 63 of 2003 concerning Guidelines for Public Services. Service joints which are simplicity, clear and certain, openness, timely, efficient, economical, safe and comfortable.

Based on the facts above, the researcher is interested in conducting research on: "the effect of empowerment, training, compensation, through organizational commitment to the financial management performance of the North Sulawesi Provincial Government". This research was conducted to analyze and determine the effect of empowerment, training, compensation, through organizational commitment to the financial management performance of the North Sulawesi Province government. This research is important because as far as the knowledge of researchers, there is no similar topic about "the effect of empowerment, training, compensation through organizational commitment to the financial management performance of the North Sulawesi Province government so that the results of this study are expected to be a reference material for policy makers in improving performance in financial management. 


\section{LITERATURE REVIEW}

\section{Job Performance}

According to Gibson, et al (2003: 355), job performance is the result of work related to organizational goals, efficiency and effectiveness of other performance effectiveness. Mathis and Jackson (2004: 378) defines performance (basically) is what is done or not done by employees. Employee performance that is common to most jobs includes the following elements. (1) Quantity of results, (2) quality of results, (3) timeliness of results, (4) attendance, and (5) ability to work together.

\section{Organizational Commitment}

Mathis and Jackson in Sopiah (2008: 155) state that organizational commitment is the degree to which employees believe and accept organizational goals and will remain or will not leave the organization. Another definition was also put forward by Porter in Sopiah, (2008: 156) which explains that a form of commitment that appears not only is passive loyalty, but also involves an active relationship with work organizations that have the goal of giving all the effort for the success of the organization concerned.

\section{Empowerment}

Wibowo (2016: 138) states empowerment as placing workers accountable for what they do. Empowerment allows people to make bigger and more decisions without having to refer to someone more senior. Empowerment provides an opportunity for each individual or employee to participate in expressing ideas and input with efforts to provide improved performance for the organization.

\section{Training}

According to Widodo (2015: 82), training is a series of individual activities in systematically increasing expertise and knowledge so as to be able to have professional performance in their fields. Training is a learning process that allows employees to carry out work that is now in accordance with standards.

\section{Compensation}

Compensation is something that is received by employees as a reward for their achievements in carrying out their duties (Nurjaman, 2014: 179). Hasibuan (2014: 118), compensation is all income in the form of money, direct or indirect goods received by employees in return for services provided to the organization.

\section{RESEARCH METHOD}

This research uses a quantitative approach with a descriptive survey method. The population in this study are employees of financial managers in the government of North Sulawesi Province. Research respondents numbered 267 employees. Data analysis uses descriptive and verification approaches. The research model is as shown below. 


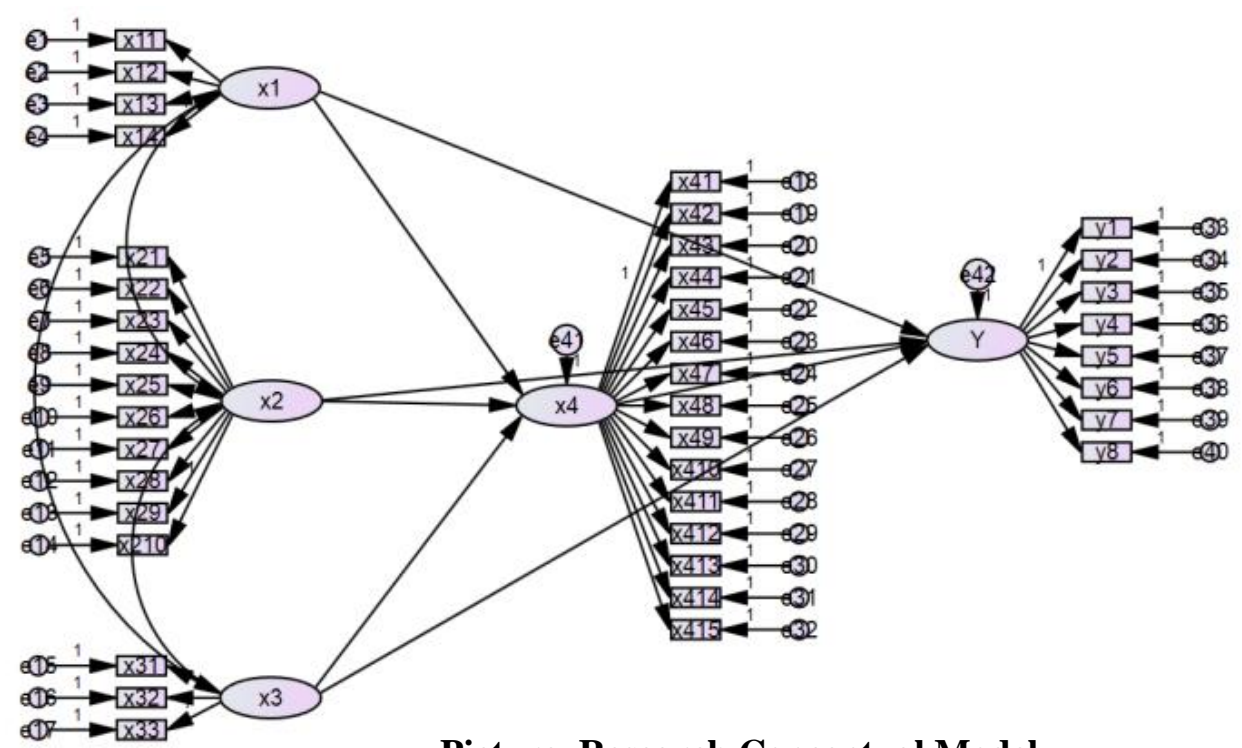

Picture. Research Conceptual Model

\section{RESULT AND DISCUSSION}

\section{Analysis Results}

\section{Structural model: testing hypotheses}

The structural model contains the path analysis which is the basis for proving hypotheses that have been prepared previously.

Table 1. Regression coefficient

\begin{tabular}{lllrl}
\hline & & & Estimate & Label \\
\hline X4 & $<---$ & X3 & .275 & par_36 \\
X4 & $<---$ & x2 & .226 & par_42 \\
X4 & $<---$ & x1 & .364 & par_36 \\
Y & $<---$ & X4 & .390 & par_38 \\
Y & $<---$ & x3 & .219 & par_40 \\
Y & $<---$ & x2 & .173 & par_41 \\
Y & $<---$ & X1 & .264 & par_39 \\
\hline
\end{tabular}

For the regression coefficient:

1. Empowerment (X1) has a regression coefficient of 0.264 on performance (Y), meaning that the higher or better the employee empowerment, the higher or better employee performance and vice versa.

2. Training (X2) has a regression coefficient of 0.173 on performance $(\mathrm{Y})$, meaning that the higher or better the training received by employees, the higher or better employee performance and vice versa.

3. Compensation (X3) has a regression coefficient of 0.219 on performance (Y), meaning that the higher or better the compensation received by employees, the higher or better the performance of employees and vice versa.

4. Organizational Commitment (X4) has a regression coefficient of 0.390 on performance (Y), meaning that the higher or better the organizational commitment, the higher or better employee performance and vice versa. 
5. Empowerment (X1) has a regression coefficient of 0.364 to organizational commitment (X4), meaning that the higher or better the empowerment (X1), the higher or better organizational commitment (X4) and vice versa.

6. Training (X2) has a regression coefficient of 0.226 to organizational commitment (X4), meaning that the higher or better the training (X2), the higher or better organizational commitment (X4) and vice versa.

7. Compensation (X3) has a regression coefficient of 0.275 to organizational commitment (X4), meaning that the higher or better the compensation (X3), the higher or better the organizational commitment (X4) and vice versa.

Table 2. Structural Model or path analysis (hypothesis testing)

\begin{tabular}{llrlcll}
\hline & & Estimate & S.E. & \multicolumn{2}{c}{ C.R. } & \multicolumn{2}{c}{ PLabel } \\
\hline x4 <--- & x1 & .364 & .075 & 4.842 & $* * *$ & par_36 \\
x4 <--- & x3 & .275 & .083 & 3.302 & $* * *$ & par_37 \\
x4 <--- & x2 & .226 & .068 & 3.330 & $* * *$ & par_42 \\
$\mathrm{Y}<----$ & x4 & .390 & .064 & 6.071 & $* * *$ & par_38 \\
$\mathrm{Y}<---$ & x1 & .264 & .061 & 4.343 & $* * *$ & par_39 \\
$\mathrm{Y}<---$ & x3 & .219 & .066 & 3.296 & $* * *$ & par_40 \\
$\mathrm{Y}<---$ & x2 & .173 & .052 & 3.320 & $* * *$ & par_41 \\
\hline
\end{tabular}

Source: Processed Data

For hypothesis testing:

1. Hypothesis 1. Empowerment (X1) has a direct and positive effect on performance (Y), as evidenced by having a probability level below $5 \%(0,000)$ and a positive direction.

2. Hypothesis 2. Training (X2) has a direct and positive effect on performance (Y). Proven because it has a probability level under $5 \%(0,000)$ and a positive direction

3. Hypothesis 3. Compensation (X3) has a direct and positive effect on performance (Y). Proven because it has a probability level under $5 \%(0,000)$ and a positive direction

4. Hypothesis 4. Organizational Commitment (X4) has a direct and positive effect on performance (Y). Proven because it has a probability level under $5 \%(0,000)$ and a positive direction.

5. Hypothesis 5. Empowerment (X1) has a direct and positive effect on organizational commitment (X4). Proven because it has a probability level under 5\% (0.00) and positive direction

6. Hypothesis 6. Training (X2) has a direct and positive effect on organizational commitment (X4). Proven because it has a probability level under 5\% (0.00) and positive direction.

7. Hypothesis 7. Compensation (X3) has a direct and positive effect on organizational commitment (X4). Proven because it has a probability level under 5\% (0.00) and positive direction.

Table 3. Indirect Effect

\begin{tabular}{crrrrr}
\hline & $\mathrm{x} 3$ & $\mathrm{x} 2$ & $\mathrm{x} 1$ & $\mathrm{x} 4$ & $\mathrm{Y}$ \\
\hline $\mathrm{x} 4$ & .000 & .000 & .000 & .000 & .000 \\
$\mathrm{Y}$ & .107 & .088 & .142 & .000 & .000 \\
\hline \multicolumn{3}{l}{ Source: Processed Data }
\end{tabular}

Indirect the biggest effect in this research model was contributed by employee empowerment (X1) on performance (Y) of 0.142 .

For hypotheses involving indirect elements, they use several stages of analysis because there must be significant requirements on each direct path to be tested for their indirect relationships. And for the arguments summarized in the table below: 
Table 4. Relationship Test

\begin{tabular}{|l|l|l|}
\hline \multicolumn{1}{|c|}{ Hypothesis tested } & $\begin{array}{c}\text { The value and direction of } \\
\text { the indirect relationship }\end{array}$ & Conclusion \\
\hline $\begin{array}{l}\text { Hypothesis 8. } \\
\text { Employee Empowerment has an } \\
\text { indirect and positive effect on } \\
\text { employee performance through } \\
\text { organizational commitment. }\end{array}$ & 0.142 and positive & be accepted \\
\hline $\begin{array}{l}\text { Hypothesis 9. } \\
\text { Employee Training has an indirect and } \\
\text { positive effect on employee } \\
\text { performance through organizational } \\
\text { commitment. }\end{array}$ & 0.088 and positive & be accepted \\
\hline $\begin{array}{l}\text { Hypothesis 10. } \\
\text { Employee Compensation has an } \\
\text { indirect and positive effect on } \\
\text { employee performance through } \\
\text { organizational commitment. }\end{array}$ & 0.107 and positive & be accepted \\
\hline
\end{tabular}

\section{Discussion}

Based on the results of testing statistical research hypotheses. The research findings are explained descriptively and verification, which are then compared with the theories and results of previous studies.

\section{Hypothesis 1 Empowerment of employees has a direct and positive effect on employee performance.}

The results showed that the first hypothesis was accepted. Employee empowerment $\left(\mathrm{X}_{1}\right)$ has a direct and positive effect on employee performance (Y), as evidenced by having a probability level below $5 \%(0,000)$ and a positive direction.

The results of the study prove empirically the empowerment of employees influences employee performance. The results of research that prove that Fadzilah (2006: 13) that one of the factors that can affect employee performance is employee empowerment. Employee performance will increase if the empowerment of employees in the organization also increases. According to Fadzilah (2006: 13) that empowerment in addition to influencing performance improvement, can also cause employees to have the desire to end a task or leave the organization. Individuals who feel satisfied with their work tend to survive in the organization, while individuals who feel less satisfied with their work will choose to leave the organization. Thus it is evident that employee empowerment affects the performance of employees.

\section{Hypothesis 2 Employee training has a direct and positive effect on employee performance.}

The results showed that the second hypothesis was accepted. Employee training $\left(\mathrm{X}_{2}\right)$ has a direct and positive effect on employee performance (Y), as evidenced by having a probability level below $5 \%(0,000)$ and a positive direction.

The results of the study prove empirically employee training has an effect on employee performance. Triasmoko, et al (2014: 1) research results prove that the test results partially 
variable training methods significantly influence employee performance variables. This means that if employees are included in the training will have an impact on the better performance of the employee, and vice versa if the employee lacks training will have an impact on employee performance that will not be maximized. Employee training is very important in an organization. An effective organization must be able to find, utilize, maintain, and develop humans to achieve the desired results (Marwansyah, 2012: 3).

\section{Hypothesis 3 Employee compensation has a direct and positive effect on employee performance.}

The results showed that the third hypothesis was accepted. Employee compensation $\left(\mathrm{X}_{3}\right)$ has a direct and positive effect on employee performance (Y), as evidenced by having a probability level below $5 \%(0,000)$ and a positive direction.

The results of the study prove empirically employee compensation affect employee performance. Mundakir and Zainuri's research results (2018: 43) prove that compensation influences employee performance. From the results of this study it appears that the better the compensation provided by the organization to employees, the better and more positive the performance of employees. Conversely the weaker the compensation or compensation that is not in line with the expectations of the employee, the employee's performance will also weaken. The purpose of providing compensation, among others, is for employee performance which will later maintain the stability of the employee itself so that later it will be able to reduce turnover rates. Providing appropriate compensation and in accordance with the energy and capabilities expended is expected to make employees more satisfied with their work so they can be professional.

\section{Hypothesis 4 Organizational commitment directly and positively influences employee performance.}

The results showed that the first hypothesis was accepted. Organizational commitment $\left(\mathrm{X}_{4}\right)$ has a direct and positive effect on employee performance $(\mathrm{Y})$, as evidenced by having a probability level below $5 \%(0,000)$ and a positive direction.

The results of the study prove empirically organizational commitment effect on employee performance. Nurandini and Lataruva's research results, (2014: 89) prove that organizational commitment is proven to affect an employee's performance. If the organizational commitment is good then the employee's performance will be good, but conversely if the organizational commitment is not good it will have an impact on the decline in the performance of the employee. The results of this study are in line with research conducted by Pane and Fatmawati (2017:) that organizational commitment influences employee performance. Attachment between independent variables, namely commitment consisting of affective commitment, normative commitment, and continuous commitment together with Employee Performance is very strong.

\section{Hypothesis 5 Empowering employees directly and positively influences organizational commitment.}

The results showed that the first hypothesis was accepted. Employee Empowerment $\left(\mathrm{X}_{1}\right)$ has a direct and positive effect on organizational commitment $\left(\mathrm{X}_{4}\right)$, as evidenced by having a probability level below $5 \%(0,000)$ and a positive direction.

The results of the study prove empirically the empowerment of employees influences organizational commitment. The results of the research of Setiawan and Piartrini (2018: 187) show that employee empowerment has a positive and significant effect on organizational commitment. The higher the employee empowerment policy that is provided, the higher the organizational commitment. Wibowo (2012: 409) explained empowerment as a process to make people become more empowered or more capable of solving their own problems by giving them trust and authority, so as to foster a sense of responsibility. Empowerment is one of the most effective techniques for increasing employee productivity and optimal use of the capacity and abilities of individuals or groups in accordance with organizational goals. 


\section{Hypothesis 6 Employee training has a direct and positive effect on organizational commitment.}

The results showed that the first hypothesis was accepted. Employee Training $\left(\mathrm{X}_{1}\right)$ has a direct and positive effect on organizational commitment $\left(\mathrm{X}_{4}\right)$, as evidenced by having a probability level below $5 \%(0,000)$ and a positive direction.

The results of the study prove empirically employee training influences the organizational commitment of employees. The research results of Nugraha et al (2017: 61) show that there is a direct positive effect of training on organizational commitment. The better the training that employees attend, the better the organizational commitment. Luthans (2006: 249) defines organizational commitment as an attitude that reflects employee loyalty to the organization and is an ongoing process where every member of the organization devotes their attention to the organization, organizational success and organizational progress.

\section{Hypothesis 7 Employee compensation has a direct and positive effect on organizational commitment.}

The results showed that the first hypothesis was accepted. Employee Compensation $\left(\mathrm{X}_{1}\right)$ has a direct and positive effect on organizational commitment $\left(\mathrm{X}_{4}\right)$, as evidenced by having a probability level below $5 \%(0,000)$ and a positive direction.

The results of the study prove empirically the compensation received by employee employees affect the organizational commitment of the employee. Pratama et al's research results (2016: 1) prove that employee compensation has a significant partial effect on employee organizational commitment. This means that the better the compensation received by the employee, the better the organizational commitment of the employee. Compensation is anything that the employee receives as a remuneration that is able to provide satisfaction to the employee for the work that has been completed. Compensation received by employees is divided into two types of financial compensation and non-financial compensation. Inadequate compensation received by employees will reduce the sense of organizational commitment of employees, job satisfaction and work motivation (Fatimah, 2013 in Pratama et al, 2016: 2).

\section{Hypothesis 8 Empowerment of employees $\left(X_{1}\right)$ has an indirect and positive effect on employee performance $(Y)$ through organizational commitment $\left(\mathbf{X}_{4}\right)$.}

The results showed that the seventh hypothesis was accepted. Employee empowerment $\left(\mathrm{X}_{1}\right)$ has an indirect and positive effect on employee performance $(\mathrm{Y})$ through proven organizational commitment $\left(\mathrm{X}_{4}\right)$. The results of the study prove empirically through Setyawan's research (2017: 105) that there is an influence of empowerment, Self Efficacy, Organizational commitment to employee performance.

\section{Hypothesis 9 Employee training $\left(\mathrm{X}_{2}\right)$ has an indirect and positive effect on employee performance $(\mathbf{Y})$ through organizational commitment $\left(\mathbf{X}_{4}\right)$.}

The results showed that the seventh hypothesis was accepted. Employee training $\left(\mathrm{X}_{1}\right)$ has an indirect and positive effect on employee performance $(\mathrm{Y})$ through proven organizational commitment $\left(\mathrm{X}_{4}\right)$. The results of the study prove empirically through Anisah's research results (2017: 40) that the effectiveness of training and work environment through commitment simultaneously has a positive and significant effect on employee performance.

\section{Hypothesis 10 Employee compensation $\left(X_{3}\right)$ has an indirect and positive effect on employee performance $(\mathbf{Y})$ through organizational commitment $\left(\mathbf{X}_{4}\right)$.}

The results showed that the seventh hypothesis was accepted. Employee compensation $\left(\mathrm{X}_{3}\right)$ has an indirect and positive effect on employee performance $(\mathrm{Y})$ through organizational commitment $\left(\mathrm{X}_{4}\right)$ proven. The results of the study prove empirically through the results of Indriyanto's research, (2013: 83) that organizational commitment and compensation affect employee performance. This means that if organizational commitment is higher than employee 
performance will also increase and if compensation is higher than employee performance will also increase. The results of this study are reinforced by previous research conducted by Triyono (2008: 52) which states that organizational commitment and compensation together have a positive and significant effect on employee performance.

\section{CONCLUSION AND RECOMMENDATION}

The results of this study indicate that 1) Empowerment has a direct and positive effect on the performance of financial management employees. The better employee empowerment will improve the performance of financial management employees. 2) Training has a direct and positive effect on the performance of financial management employees. The better the employee training system will improve the performance of financial management employees. 3) Compensation has a direct and positive effect on the performance of financial management employees. The better the system of giving compensation to employees will improve the performance of financial management employees. 4) Organizational commitment has a direct and positive effect on the performance of financial management employees. The higher organizational commitment of employees will improve the performance of financial management employees. 5) Empowerment of employees has a direct and positive effect on organizational commitment of financial management employees. The better employee empowerment will increase the organizational commitment of financial management employees. 6) Employee training has a direct and positive effect on organizational commitment of financial management employees. The better the employee training system will increase the organizational commitment of financial management employees. 7) Compensation has a direct and positive effect on organizational commitment of financial management employees. The better the system of giving compensation to employees will increase the organizational commitment of financial management employees. 8) Empowerment of employees has an indirect and positive effect on employee performance through organizational commitment. 9) Employee Training has an indirect and positive effect on employee performance through organizational commitment. 10) Employee compensation has an indirect and positive effect on employee performance through organizational commitment.

\section{REFERENCES}

Anisah 2017. Pengaruh Efektivitas Pelatihan Dan Lingkungan Kerja Terhadap Komitmen Keorganisasian Serta Dampaknya Terhadap Kinerja Pegawai Pada PT. Jasa Raharja Cabang Jambi. Jurnal of Economics and BusinessVol.1 No.1 September 2017.

Fadzilah, A. 2006. Analisis Pengaruh Pemberdayaan Karyawan Dan Self Of Efficacy Terhadap Kinerja Karyawan Bagian Penjualan (Studi Kasus Pada PT. Sinar Sosro Wilayah Pemasaran Semarang). Jurnal Studi Manajemen dan Organisasi Volume 3, Nomor 1, Januari, Tahun 2006, p. 12-27.

Gibson, J. L., J. M., Ivancevich dan J. H.,Donnelly, Jr., 2003. Organizations : Behavior Structure Processes. Eleventh Edition. New York : Mc Graw Hill.

Gibson, J. L., J. M., Ivancevich dan J. H.,Donnelly, Jr., 2008, Organisasi dan Manajemen: Perilaku, Struktur, dan proses, terjemahan oleh Joerban Wahid, Erlangga, Jakarta.

Hasibuan, M., 2014. Manajemen Sumber Daya Manusia. Jakarta: Bumi. Aksara.

Indrayanto, A. dan S. W. D. Nugroho., 2013. Pengaruh Pelatihan Terhadap Komitmen Organisasional Dengan Organisational Based Self-Esteem Sebagai Variabel Pemediasi. Performance Business and Managemen Jurnal. Vol 18, No 2.

Indriyanto, D. Y. 2013. Pengaruh Komitmen Organisasional Dan Kompensasi Terhadap Kinerja Karyawan Di Balai Penelitian Dan Pengembangan Agama Semarang. Universitas Negeri Semarang.

Luthans, F. 2006. Perilaku Organisasi. Edisi Sepuluh, PT. Andi: Yogyakarta.

Mathis, R. L dan Jackson, J. H., 2001. Manajemen Sumberdaya Manusia. Buku 1, Salemba Empat Jakarta. 
Marwansyah. 2012. Manajemen Sumber Daya Manusia. Edisi kedua. Bandung. Alfabeta.

Mundakir dan Zainuri, 2018. Pengaruh Kompensasi Dan Motivasi Terhadap Kinerja Pegawai Negeri Sipil Dengan Kepuasan Kerja Sebagai Variabel Intervening. Business Management Analysis Journal (BMAJ) Vol. 1 No. 1 - Oktober 2018. P : 47-48.

Nugraha, R. S., Setiawan, M dan Puspaningrum, A. 2017. Komitmen Organisasional Sebagai Mediasi Pengaruh Pelatihan Dan Disiplin Kerja Terhadap Kinerja Pegawai (Studi pada Dinas Pendapatan Pengelolaan Keuangan dan Asset Kabupaten Malang). Jurnal Bisnis dan Manajemen Vol. 4 No.1, Januari 2017. P : 55-63.

Nurjaman, K., 2014. Manajemen Personalia. Bandung : CV Pustaka Setia.

Nurandini, A. dan Lataruva, E. 2014. Analisis Pengaruh Komitmen Organisasi Terhadap Kinerja Karyawan (Studi Pada Pegawai Perum PERUMNAS Jakarta). Jurnal Studi Manajemen \& Organisasi 11 (2014) Juni 78 - 91.

Pane, S. G., dan Fatmawati. 2017. Pengaruh Komitmen Organisasi Terhadap Kinerja Pegawai Pada Badan Pertanahan Nasional Kota Medan. Jurnal Riset Manajemen \& Bisnis (JRMB) Vol. 2. No.3. Oktober 2017. P : 67-79.

Pratama, E. W., M. Al Musadieq, dan Y. Mayowan, 2016. Pengaruh Kompensasi Dan Kepusan Kerja Terhadap Komitmen Organisasional (Studi pada Karyawan KSP Sumber Dana Mandiri Gresik). Jurnal Administrasi Bisnis (JAB)|Vol. 34 No. 1 Mei 2016. P : 1-9.

Setiawan, I. P. I dan Piartrini, P. S., 2018. Pengaruh Pemberdayaan Karyawan Dan Stres Kerja Terhadap Komitmen Organisasional Karyawan Departemen Housekeeping Pada Villa Ocean Blue. E-Jurnal Manajemen Unud, Vol. 7, No. 1, 2018: 164-191.

Setyawan, S. 2017. Pengaruh Self Efficacy Dan Pemberdayaan Terhadap Kinerja Pegawai Dengan Mediasi Komitmen Organisasional. Jurnal Akses Volume 12 Nomor 24 Oktober 2017.

Sopiah, 2008. Perilaku Organisasi, Yogyakarta: Andi Offset.

Triasmoko, D., Mukzam, M. D. dan Nurtjahjono, G. E. 2014. Pengaruh Pelatihan Kerjaterhadap Kinerja Karyawan (Penelitian pada Karyawan PT Pos Indonesia (Persero) Cabang Kota Kediri) Jurnal Administrasi Bisnis (JAB)|Vol. 12 No. 1 Juli 2014. P 1-10.

Triyono, 2008. Analisis Perubahan Kurs Rupiah Terhadap Dollar Amerika. Ekonomi PembangunanVol. 9, No. 2, Desember, hal. 156 -167.

Wibowo, 2016. Manajemen Kinerja. Edisi 5, Cetakan 10. Jakarta: Raja Grafindo Persada.

Wibowo. 2012. Manajemen Perubahan. Edisi Ketiga. Jakarta : Rajawali Pers

Widodo, E. S., 2015. Manajemen Pengembangan Sumber Daya. Manusia. Yogyakarta: Pustaka Pelajar. 